\title{
PENINGKATAN HASIL BELAJAR DENGAN METODE PICTURE AND PICTURE PADA MATERI PECAHAN KELAS II SD MUHAMMADIYAH 9 SURABAYA MASA PANDEMI COVID-19
}

\author{
Faizal Anas Aditya ${ }^{1}$, Kunti Dian Ayu Afiani ${ }^{2}$, Meirza Nanda Faradita ${ }^{3}$ \\ 1. Universitas Muhammadiyah Surabaya \\ faizal.anas.aditya-2020@fkip.um-surabaya.ac.id \\ ${ }^{2}$ Universitas Muhammadiyah Surabaya \\ kuntidianayu@fkip.um-surabaya.ac.id \\ ${ }^{3}$ Universitas Muhammadiyah Surabaya \\ meirzananda@fkip.um-surabaya.ac.id
}

\begin{abstract}
Abstrak
Penelitian ini bertujuan untuk Untuk mengatahui adanya peningkatkan hasil belajar siswa, Untuk mengetahui adanya peningkatkan aktivitas siswa, Untuk mengetahui adanya peningkatan aktivitas guru dalam mengelola pembelajaran dengan metode picture and picture pada materi pecahan kelas II SD Muhammadiyah 9 Surabaya masa pandemi covid-19. Jenis penelitian ini adalah Penelitian Tindakan Kelas (PTK) yang dilakukan dalam tahapan siklus meliputi tahap perencanaan, pelaksanaan, pengamatan dan refleksi. Subjek Penelitian Tindakan Kelas ini adalah siswa kelas II SD Muhammadiyah 9 Surabaya yang berjumlah 34 siswa. Objek penelitian ini adalah hasil belajar pada materi mengenal pecahan. Instrumen yang digunakan dalam penelitian ini adalah lembar observasi dan soal tes. Data hasil penelitian dianalisis secara deskriptif kualitatif dan kuantitatif. Indikator keberhasilan penelitian ini adalah jika minimal $75 \%$ siswa telah mencapai KKM yaitu 75 dan nilai rata-rata kelas telah mencapai KKM. Hasil penelitian menunjukkan adanya peningkatan.berdasarkan Hasil belajar siswa secara klasikal meningkat sebesar $23 \%$
\end{abstract}

Kata kunci: Pecahan, Metode Picture and picture, Pandemi Covid-19

\begin{abstract}
This study aims to find out if there is an increase in student learning outcomes, to find out an increase in student activity, to find out an increase in teacher activity in managing learning using the picture and picture method in class II fraction material at SD Muhammadiyah 9 Surabaya during the covid-19 pandemic. This type of research is Classroom Action Research (CAR) which is carried out in cycle stages including planning, implementation, observation and reflection stages. The subject of this Classroom Action Research is the second grade students of SD Muhammadiyah 9 Surabaya, totaling 34 students. The object of this research is the result of learning in the matter of recognizing fractions. The instruments used in this study were observation sheets and test questions. The research data were analyzed descriptively qualitatively and quantitatively. The indicator of the success of this research is if at least $75 \%$ of students have reached the KKM, which is 75 and the average grade has reached the KKM. The results showed an increase. Based on student learning outcomes classically increased by $23 \%$
\end{abstract}

Keywords: Fractions, Picture and picture method, Covid-19 pandemic 
Pendahuluan

Pesatnya perkembangan zaman dan adanya era globalisasi menuntut setiap manusia untuk siap menghadapi persaingan antar manusia. Persaingan dapat bertahan jika memiliki kualitas sumber daya manusia yang baik. Kesadaran tentang pentingnya pendidikan telah mendorong berbagai upaya dan perhatian seluruh lapisan masyarakat terhadap setiap perkembangan dunia pendidikan (Mulyani, Perkembangan peserta didik :2014).

Keberhasilan proses pembelajaran sebagai proses pendidikan di suatu sekolah dipengaruhi oleh banyak faktor. Faktor-faktor yang dimaksud misalnya guru, siswa, kurikulum, lingkungan sosial, dan lain-lain (Zain,dkk 1997:48). Namun dari faktor-faktor itu, guru dan siswa faktor terpenting. Pentingnya faktor guru dan siswa tersebut dapat dirunut melalui pemahaman hakikat pembelajaran yakni sebagai usaha sadar guru untuk membantu siswa agar dapat belajar dengan kebutuhan minatnya. Seorang siswa tidak dapat berkembang tanpa belajar, demikian juga bagi seorang guru. Guru sebagai unsur penting dalam keberhasilan siswanya harus memahami betul hakekat belajar.
Para ahli mengemukakan pendapatnya berkaitan dengan pengertian belajar. Salah satunya adalah pengertian belajar menurut (Surya, 2009;32), yaitu proses usaha yang dilakukan individu untuk memperoleh suatu perubahan tingkah laku yang baru keseluruhan sebagai pengalaman individu itu sendiri dengan lingkungan. Menurut (Afiani \& Putra, 2017) pembelajaran yang kreatif dan inovatif yang berpusat pada siswa adalah kewajiban guru

Pendidikan dapat diperoleh dari pengalaman individu maupun pengalaman dalam lingkungan disektar. Seperti contohnya siswa dapat belajar meskipun tidak didalam ruang kelas akan tetapi siswa dapat juga belajar dilingkungan sekitarnya dengan cara menggunakan objek atau contoh kongkrit yang ada pada benda disekitarnya.

Seorang siswa tidak dapat berkembang tanpa belajar, demikian juga bagi seorang guru. Guru sebagai unsur penting dalam keberhasilan siswanya harus memahami betul hakekat belajar. Hal ini agar siswa mampu belajar secara tepat sehingga akan berpengaruh terhadap hasil pembelajaran yang telah dilaluinya. Banyak para ahli yang mengemukakan pendapatnya berkaitan dengan pengertian belajar. Salah satunya adalah pengertian belajar menurut Gagne 
(dalam Anita, 2014), bahwa belajar adalah suatu proses dimana suatu organisme berubah perilakunya sebagai akibat pengalaman.

Matematika adalah ilmu dasar yang berkembang pesat baik materi maupun kegunaannya dalam kehidupan sehari hari. Dalam kurikulum tiga belas, matematika merupakan salah satu pelajaran yang diujikan dalam ujian nasional yang sangat menentukan kelulusan siswa. Oleh karena itu, siswa secara sadar mengakui pentingnya matematika, bahkan orang tua harus memaksa anaknya mengikuti pelajaran tambahan Ini membuat anak mereka membenci matematika. Akibatnya siswa kesulitan memahami dan menguasai matematika.

Berdasarkan wawancara dengan guru kelas II, dalam wawancara tersebut beliau menjelaskan bahwa masih banyak kegagalan siswa dalam matematika bukan terletak pada kurikulum, tapi lebih pada cara mengajarkan bidang studi. Saat ini masih banyak guru yang menggunakan pendekatan latihan untuk mengembangkan kemampuan berfikir melalui latihan berulang dan menghafal rumus rumus. Guru sangat mendominasi dalam menentukan semua kegiatan pembelajaran dikelas. Siswa datang ke sekolah, duduk, mendengarkan, mencatat, menjawab pertanyaan, menghafal, dan mengerjakan soal soal dari guru. Suatu pembelajaran yang tidak efektif baik bagi guru maupun siswa sebab dengan demikian guru dapat menyelesaikan bahan kurrikulum sesuai dengan tuntutan dan mementingkan hasil objektifitas.

Berdasarkan hasil belajar dan observasi, bahwa dalam pembelajaran Matematika untuk materi tentang mengenal pecahan pada sekolah tersebut tidak menggunakan media picture and picture, hanya menggunakan metode ceramah karena belum mampu untuk menerapkannya dalam proses pembelajaran, dilain pihak banyak siswa yang sudah bosan dengan metode ceramah sehingga pembelajaran yang diharapkan belum tercapai dan hasil prestasi belajar belum maksimal.

Salah satu materi yang jadi masalah dalam mata pelajaran matematika yang dihadapi oleh siswa kelas II SD Muhammadiyah 9 adalah mengenal pecahan. Pada materi ini ada 25 siswa dari jumlah total 34 siswa dalam satu kelas yang masih memiliki nilai dibawah KKM. Siswa seharusnya bisa menguasai materi mengenal pecahan dengan baik. Materi tersebut sebenarnya mudah untuk difahami jika metode atau media yang digunakan dalam menjelaskan kepada siswa benar dan mudah untuk difahami siswa seperti menggunakan media 
pembelajaran yang nyata atau konkrit sehingga siswa lebih jelas dan mengerti.

Salah satu model pembelajaran yang memungkinkan siswa belajar secara efektif dan efisien adalah menggunakan metode picture and picture. Seperti yang sudah dilakukan dalm beberapa penelitian contohnya : Model Pembelajaran Picture and Picture untuk meningkatkan Pemahaman Sejarah E Septiady : 2017, Penerapan Metode Picture and Picture dengan menggunakan Cerita Gambar Berseri Untuk Meningkatkan Perkembangan Bahasa Pada Anak NNL (Trisnawati, 2014), Meningkatkan Hasil Belajar Siswa Melalui Media Picture and Picture Pada Materi Penerapan sila-sila Pancasila (Maulidya, 2017). Melalui media picture and picture diharapkan dapat mempercepat peningkatan mutu pendidikan melalui penyelenggaraan proses pembelajaran yang berkualitas. Oleh karena itu model pembelajaran tersebut perlu disosialisasikan pada guru agar dapat diaplikasikan dalam proses pembelajaran. Hal tersebut dimaksudkan supaya guru tidak ketinggalan inovasi dalam penerapan model pembelajaran inovatif.

Pembelajaran menggunakan metode picture and picture merupakan salah satu model pembelajaran aktif yang memberikan kesempatan bagi siswa untuk

membagi ide-ide, mempertimbangkan jawaban yang paling tepat dan menjawab pertanyaan secara lisan sehingga menumbuhkan rasa percaya diri siswa dalam mengemukakan ide atau jawaban di depan kelas (Kurniasih, Imas, Berlin 2015:44).

Metode picture and picture merupakan salah satu dari sekian banyak metode pembelajaran yang menggunakan gambar sebagai media yang dapat diperoleh dari sumber buku, majalah, internet dan foto sesuai dengan materi dan tujuan pembelajaran.(Hamdani 2011:89) Salah satu metode yang saat ini popular dalam pembelajaran adalah metode pembelajaran picture and picture, model ini merupakan salah satu bentuk model pembelajaran kooperatif.

Pembelajaran modern memiliki ciri Aktif, Inovatif, Kreatif, dan Menyenangkan. Model apapun yang digunakan selalu menekankan aktifnya murid dalam setiap proses pembelajaran. Inovatif, setiap pembelajaran harus memberikan sesuatu yang baru, berbeda dan selalu menarik minat murid, serta kreatif. Setiap pembelajaran harus menimbulkan minat kepada murid untuk menghasilkan sesuatu atau dapat menyelesaikan suatu masalah dengan menggunakan metoda, teknik atau cara yang dikuasai oleh murid 
itu sendiri yang diperoleh dari proses pembelajaran (Wilantara dkk,2016).

Metode pembelajaran picture and picture memiliki kelebihan (Trianto. 2009:12), yaitu :

1. Dapat memperbesar perhatian daA motivasi siswa terhadap materi yang dipelajari.

2. Penggunaan media gambar dapat mengurangi verbalisme, gambar/foto yang diperoleh melalui internet memberikan pengalaman belajar lebih

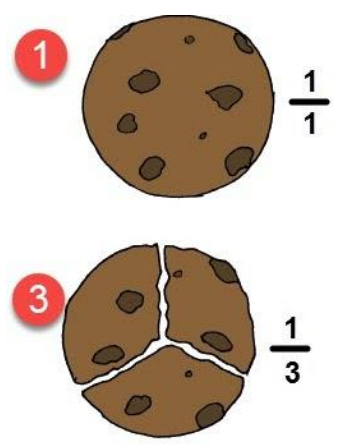

RINTOKUSMIRAN.COM

\section{Gambar 1: Pecahan Biskuit}

(Pembelajaran 1 subtema 4)

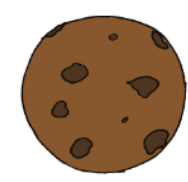

Satu biskuit dinyatakan dalam lambang pecahan biasa $\frac{1}{1}$ dibaca satu persatu.

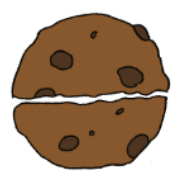

Satu biskuit dipotong menjadi dua bagian sama besar, dinyatakan dalam lambang pecahan biasa $\frac{1}{2}$, dibaca satu per dua.

RINTOKUSMIRAN.COM

\section{Gambar 2: Penjelasan gambar Pecahan Bikuit} (Pembelajaran 1 subtema 4) 
Berdasarkan permasalahan di atas maka tujuan penelitian ini adalah untuk (1) Untuk mengatahui adanya peningkatkan hasil belajar siswa, (2) Untuk mengetahui adanya peningkatkan aktivitas siswa dan (3) Untuk mengetahui adanya peningkatan aktivitas guru dalam mengelola pembelajaran.

\section{Metode Penelitian}

Jenis penelitian ini adalah menggunakan metode Picture and Picture dengan menggunakan jenis penelitian PTK. PTK (penelitian Tindakan kelas) merupakan kegiatan penelitian yang dilakukan terhadap sejumlah subjek yang menjadi sasaran yaitu peserta didik, bertujuan memperbaiki situasi pembelajaran di kelas agar terjadi peningkatkan kualitas pembelajaran (Arikunto 2010).

Dalam pelaksanaannya, penelitian tindakan kelas ini menggunakan model Kurt Lewin yang menyatakan bahwa dalam satu siklus terdiri dari empat langkah pokok yaitu : (1) perencanaan (planning), (2) aksi atau tindakan (acting), (3) observasi (observing), dan (4) refleksi (reflecting).

Berdasarkan fokus perbaikan dalam pembelajaran Matematika, maka langkah-langkah yang diambil dalam rencana perbaikan adalah sebagai berikut:

\section{a. Perencanaan}

Rancangan yang ditetapkan dalam penelitian ini adalah penggunaan metode Picture and picture. Dalam tahap perencanaan peneliti membuat perencanaan sebagai berikut : Menelaah pembelajaran Matematika pada materi mengenal pecahan. (2) Menyusun Rencana Pelaksanaan Pembelajaran (RPP) (3) Menyiapkan lembar observasi yang akan digunakan dalam penelitian. (4) Menyiapkan alat evaluasi.

\section{b. Pelaksanaan}

Penelitian ini dilaksanakan dengan beberapa tahap yakni : (1) Siklus 1 : Dilaksanakan dengan simulasi pembelajaran melalui media Power Point karena terkait dengan wabah COVID 19. (2) Siklus 2 : Dilaksanakan dengan simulasi pembelajaran melalui media Power point karena terkait dengan wabah COVID 19.

\section{Pengamatan}

Kegiatan

pengamatan dilaksanakan dengan mengamati respon siswa pada setiap pembelajaran langsung dan dalam setiap simulasi pembelajaran siklus 1 dan 2 .

\section{d. Refleksi}

Pada akhirnya setelah mengkaji hasil belajar Matematika dan hasil pengamatan aktivitas guru, serta 
memperhatikan indicator kinerja maka peneliti melakukan perbaikan pada siklus dua agar pelaksanaan pembelajaran lebih efektif dan hasil pembelajaran menjadi lebih baik.

\section{Teknik Pengumpulan Data}

Teknik pengumpulan data yang dilakukan pada penelitian ini adalah :

a. Observasi aktivitas guru dan siswa Pada teknik ini data diperoleh dari hasil observasi aktivitas guru dan aktivitas siswa di SD Muhammadiyah 9 dengan menggunakan lembar observasi guru dan siswa.

\section{b. Tes hasil belajar.}

Pada teknik ini diperoleh dari hasil evaluasi siswa melalui lembar tes hasil belajar yang dibagikan melalui google form dengan link https://forms.gle/chZjwTpFdoXvMzDr6

\section{Teknik Analisis Data}

Teknik analisis data diperoleh dari hasil belajar siswa, aktivitas siswa, dan aktivitas guru.

\section{a. Analisis data hasil belajar}

Analisis hasil belajar didapatkan dari rumus

$$
N=\frac{\sum \text { Skor Perolehan }}{\text { Skor Maks. }} \times 100
$$

(Agip dkk, 2009:41)
( rumus nilai hasil belajar dengan nilai $\mathrm{KKM} \geq 75$ siswa dikatakan tuntas. Persentase ketuntasan klasikal sebesar $\geq 75 \%$. Adapun rumus persentase klasikal

$$
\begin{gathered}
P=\frac{\text { jumlah siswa yang tuntas }}{\text { jumlah seluruh siswa }} \\
\times 100 \%
\end{gathered}
$$

\section{b. Analisis data aktivitas siswa}

Menghitung prosentase rata-rata dari setiap kriteria untuk tiap-tiap aktivitas siswa dalam pembelajaran. Rumus yang digunakan yaitu:

Prosentase Keaktifan \%

$$
=\frac{\text { Skor maksimal }}{\text { Skor Total }} \times 100 \%
$$

Menurut Uno (2011:185) bahwa aktivitas siswa dikatakan aktif dalam pembelajaran, jika prosentase ratarata dari aktivitas siswa yang aktif mencapai $\geq 75$.

\section{c. Analisis data aktivitas guru}

Skala penilaian aktivitas guru dalam melaksanakan proses pembelajaran dibuat dengan range 1 sampai 4 dengan ketentuan sebagai berikut: 
Tabel 1: Skala Penilain Aktivitas Guru

\begin{tabular}{|c|l|l|}
\hline $\begin{array}{c}\text { Skor } \\
\text { Penilaian }\end{array}$ & Kriteria & \multicolumn{1}{|c|}{ Deskripsi } \\
\hline 4 & Sangat baik & $\begin{array}{l}\text { Dilakukan dengan sangat baik oleh guru, } \\
\text { pembelajaran sempurna dan guru terlihat } \\
\text { professional }\end{array}$ \\
\hline 3 & Baik & $\begin{array}{l}\text { Pembelajaran dilaksanakan dengan baik oleh guru, } \\
\text { pembelajaran tanpa kesalahan dan guru terlihat } \\
\text { menguasai }\end{array}$ \\
\hline 2 & Cukup & $\begin{array}{l}\text { Dilaksanakan dengan cukup baik oleh guru, } \\
\text { pembelajaran dengan sedikit kesalahan dan guru } \\
\text { sudah cukup menguasai }\end{array}$ \\
\hline 1 & Kurang & $\begin{array}{l}\text { Tidak dilaksanakan oleh guru, Pembelajaran } \\
\text { terdapat banyak kesalahan, guru terlihat tidak } \\
\text { menguasai }\end{array}$ \\
\hline
\end{tabular}

(Poerwanti, dkk 2008:7)

Data yang telah diperoleh yang diamati setiap kali pertemuan. Nilai dianalisis dengan cara menghitung nilai rata-rata tersebut selanjutnya rata-rata keseluruhan aspek kemampuan dikonversikan dengan skala sebagai guru dalam mengelola pembelajaran berikut:

Tabel 2: Skala Nilai Rata-Rata

\begin{tabular}{|c|l|}
\hline Skala & \multicolumn{1}{|c|}{ Kriteria } \\
\hline $85-100$ & Sangat Baik \\
\hline $70-84$ & Baik \\
\hline $55-69$ & Cukup Baik \\
\hline $40-54$ & Kurang \\
\hline
\end{tabular}

(Hamalik, 1989:122) 
Berdasarkan tabel diatas, Hasil dan Pembahasan

kemampuan guru dalam mengelola Berdasarkan penelitian tindakan kelas pembelajaran dikatakan efektif jika yang telah dilaksanakan sebanyak dua mencapai kriteria minimal baik. Rumus siklus yaitu siklus I pada tanggal 18 - 19 aktivitas pengelolaan guru adalah November 2021 dan siklus II pada sebagai berikut:

Nilai
$=\frac{\text { Jumlah skor yang diperoleh tiap pertemuan }}{\text { Jumlah skor maksimal }} \times 100$

(Sudjana, 2005) tanggal 25 - 26 November 2021, sebagai upaya Penerapan pembelajaran melalui media picture and picture pada materi pecahan dapat meningkatkan hasil belajar siswa kelas II SD Muhammadiyah 9 Surabaya maka hasil pembahasan di uraikan sebagai berikut:

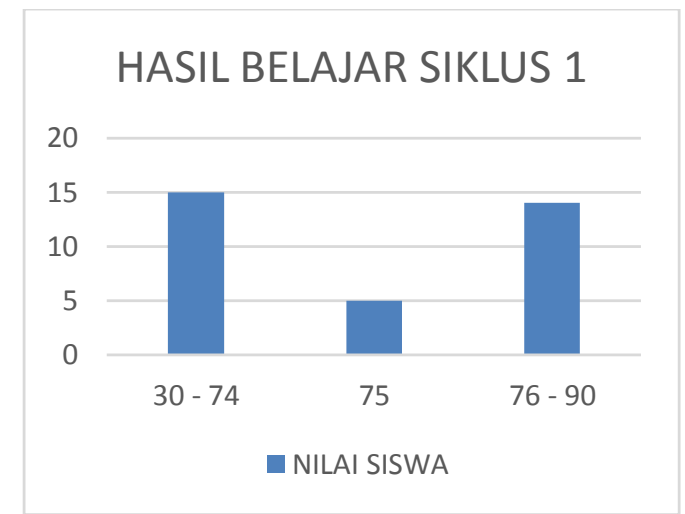

\section{Grafik 1. Hasil Belajar pada Siklus I}

Berdasarkan dari grafik I di atas maka selama hasil belajar materi pecahan siswa yang tuntas sebanyak 19 siswa dan yang belum tuntas 15 siswa, dengan KKM $\geq 75$. Persentase ketuntasan klasikal pada siklus I sebesar $56 \%$ sedangkan kriteria persentase ketuntasan klasikal $\geq$ $75 \%$, maka pada siklus I dapat dikatakan belum tuntas dengan nilai rata - rata 66,5 Aktivitas siswa .

a. Siswa mampu menyebutkan contoh lain yang sesuai dengan materi yang disampaikan oleh guru. b. Siswa aktif bertanya ketika guru menjelaskan materi pecahan.

c. Siswa mampu menentukan bilangan pecahan sesuai dengan gambar yang telah diberikan oleh guru untuk diselesaikan

d. Berdasarkan keaktifan siswa pada saat guru menyampaikan materi siswa mampu mempelajari dan mengerjakan lembar kerja dengan baik. 


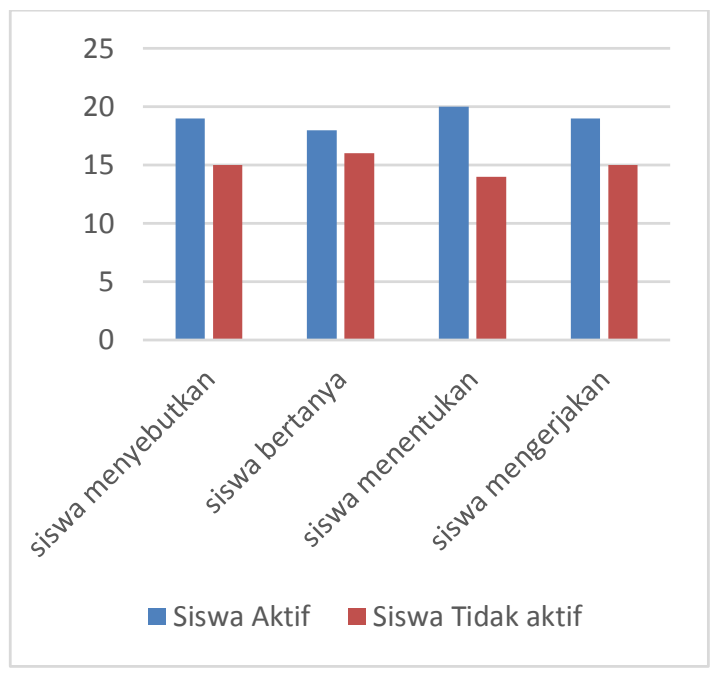

Grafik 2. Aktivitas Siswa Siklus I

Aktivitas guru.

Analisis data yang kedua pada penelitian ini adalah Observasi Aktivitas Guru dalam Mengelola Pembelajaran matematika pada materi pecahan. Pelaksanaan pembelajaran dilakukan sesuai dengan rencana pembelajaran yang telah disusun oleh guru dalam perencanaan pembelajaran. Selama berikut: pelaksanaan kegiatan berlangsung,

Tabel 3: Lembar Observasi Guru dalam Mengelola Proses Pembelajaran

\begin{tabular}{|c|c|c|c|c|c|c|}
\hline \multirow{2}{*}{ No } & \multirow[t]{2}{*}{ Pengamat } & \multirow[t]{2}{*}{ Skor } & \multicolumn{4}{|c|}{ Kriteria penilaian } \\
\hline & & & SB & B & C & $\mathbf{K}$ \\
\hline 1 & 1 & $75 \%$ & & $\sqrt{ }$ & & \\
\hline 2 & 2 & $69 \%$ & & & $\sqrt{ }$ & \\
\hline
\end{tabular}

Hasil analisis aktivitas guru dalam mengelola proses pembelajaran mendapatkan skor rata-rata $\geq 72 \%$ yang

proses pembelajaran diamati oleh dua orang observer. Bertindak sebagai observer teman sejawat yaitu Guru Kelas 2A dan Guru Kelas 3A. observasi ini dilakukan guna mengetahui sejauh mana aktivitas guru dalam mengelola proses pembelajaran. Dari hasil observasi aktivitas guru dapat dilihat melalui tabel 
diperbaiki untuk proses pembelajaran selanjutnya, sebagai berikut :

a. Penyampaian informasi pada siswa masih kurang jelas. b. Penggunaan power point kurang memberi tampilan yang menarik siswa.

c. Kurangnya pemberian penguatan kepada siswa masih sedikit.

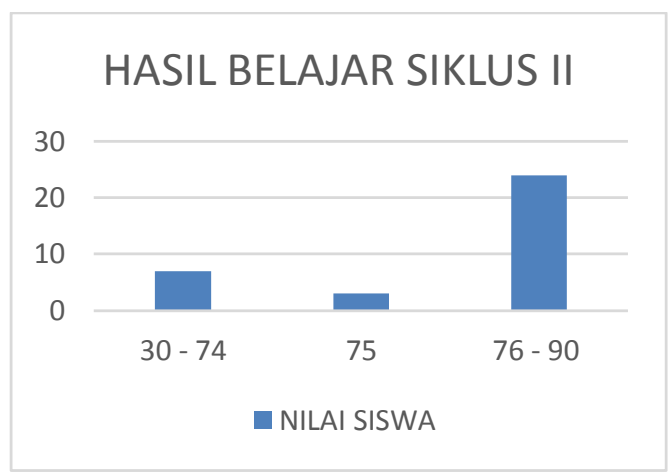

\section{Grafik 3. Nilai Hasil Belajar pada Siklus II}

Berdasarkan dari grafik II di atas maka selama hasil belajar materi pecahan siswa yang tuntas sebanyak 27 siswa dan yang belum tuntas 7 siswa, dengan KKM $\geq 75$. Persentase ketuntasan klasikal pada siklus II sebesar $79 \%$ sedangkan kriteria persentase ketuntasan klasikal $\geq$ $75 \%$, maka pada siklus II dapat dikatakan tuntas dengan nilai rata - rata 75,9.

\section{Aktivitas siswa}

a. Siswa mampu menyebutkan contoh lain yang sesuai dengan materi yang disampaikan oleh guru. b. Siswa aktif bertanya ketika guru menjelaskan materi pecahan.

c. Siswa mampu menentukan bilangan pecahan sesuai dengan gambar yang telah diberikan oleh guru untuk diselesaikan.

d. Berdasarkan keaktifan siswa pada saat guru menyampaikan materi siswa mampu mempelajari dan mengerjakan lembar kerja dengan baik. 


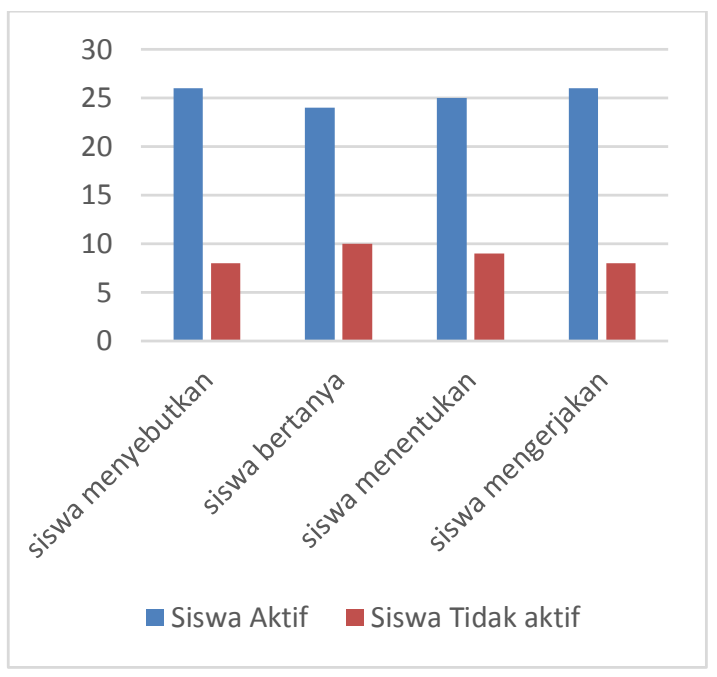

\section{Grafik 3. Aktivitas Siswa Siklus II}

\section{Aktivitas guru.}

Analisis data yang kedua pada penelitian ini adalah Observasi Aktivitas Guru dalam Mengelola Pembelajaran matematika pada materi pecahan. Pelaksanaan pembelajaran dilakukan sesuai dengan rencana pembelajaran yang telah disusun oleh guru dalam perencanaan pembelajaran. Selama berikut: pelaksanaan kegiatan berlangsung,

Tabel 4: Lembar Observasi Guru dalam Mengelola Proses Pembelajaran

\begin{tabular}{|c|c|c|c|c|c|c|}
\hline No & Pengamat & Skor & \multicolumn{3}{|c|}{ Kriteria penilaian } \\
\cline { 4 - 7 } & & & SB & B & C & K \\
\hline 1 & 1 & $80 \%$ & & $\sqrt{ }$ & & \\
\hline 2 & 2 & $85 \%$ & $\sqrt{ }$ & & & \\
\hline
\end{tabular}

Hasil analisis aktivitas guru dalam mendapatkan skor rata-rata $\geq 82 \%$ yang mengelola proses pembelajaran tergolong baik.

proses pembelajaran diamati oleh dua observer teman sejawat yaitu Guru Kelas 2A dan Guru Kelas 3A. observasi ini dilakukan guna mengetahui sejauh mana aktivitas guru dalam mengelola proses pembelajaran. Dari hasil observasi aktivitas guru dapat dilihat melalui tabel 


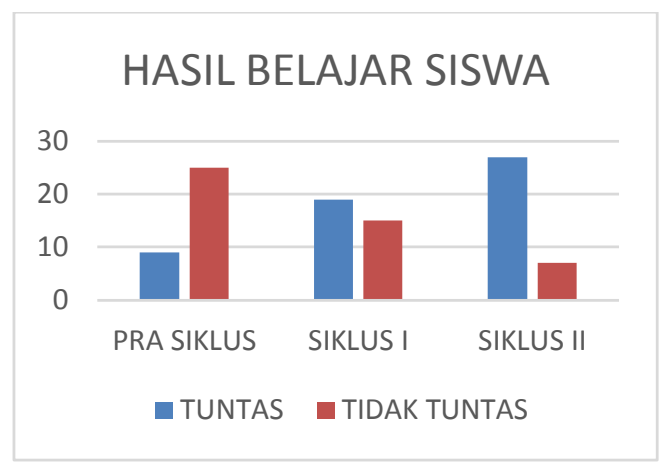

Grafik 4. Perbandingan Hasil Belajar Siswa pada pra siklus, Siklus I dan Siklus II

Berdasarkan data tentang perbaikan Kesimpulan yang telah dipaparkan pada pembahasan di atas dan dikomparasikan dengan rumusan masalah, peneliti menyimpulkan bahwa melalui media picture and picture pada materi pecahan dapat meningkatkan hasil belajar siswa kelas II SD Muhammadiyah 9. Hal ini dapat dilihat peningkatan ketuntasan belajar siswa sebelum dilakukan penelitian atau pra siklus sampai tahap siklus I dan siklus II. Pada tahap siklus I, siswa di atas KKM: 14 siswa, sesuai KKM: 5 siswa dan jumlah siswa di bawah KKM 15 siswa. Dari siswa yang mengalami ketuntasan pada siklus II yaitu siswa di atas KKM: 24 siswa, sesuai KKM: 3 siswa dan jumlah Penerapan pembelajaran matematika dapat meningkatkan hasil belajar siswa terlihat dari hasil penelitian berikut: (1) Hasil belajar siswa secara klasikal meningkat sebesar $23 \%$ dari siklus I sebesar $56 \%$ menjadi $79 \%$ pada siklus II. (2) Hasil observasi aktivitas siswa diperoleh peningkatan persentase rata-rata sebesar $23 \%$ dari siklus I sebesar $56 \%$ menjadi $79 \%$ pada siklus II dan (3) Hasil observasi pengawasan guru dalam pembelajaran matematika materi pecahan persentase rata-rata dari siklus I sebesar $10 \%$ dari siklus I sebesar $72 \%$ menjadi $82 \%$ pada siklus II.

siswa yang di bawah KKM: 7 siswa.

\section{Daftar Pustaka}

Afiani, Kunti Dian Ayu and Putra, Deni Adi (2017) Pengajuan Masalah Sebagai Alternatif Menumbuhkan Kemampuan Berpikir Kreatif Siswa. In: Seminar Nasional Kearifan Lokal Bagi Peningkatan Kualitas Pendidikan Dasar, 30 September 2017, Universitas Negeri Surabaya. http://repository.umsurabaya.ac.id/id/eprint/5317 
Agip, dkk. (2009). Penelitian Tindakan Kelas untuk Guru. Bandung: Yrama. http://repository.unpas.ac.id/30813/10/DAFTAR\%20PUSTAKA.pdf

ARIEF, M., Putra, R., \& Ermanovida, E. (2018). Peran Dinas Pendidikan Dalam Mengatasi Anak Putus Sekolah Di Kecamatan Pemulutan Selatan Kabupaten Ogan llir (Doctoral dissertation, Sriwijaya University). RINTOKUSMIRAN.COM

http://repository.unsri.ac.id/id/eprint/14707

Arikunto, S. (2010). Prosedur Penelitian Ilmiah. Rineka cipta, Jakarta.

Dial Maulidya "Meningkatkan Hasil Belajar Siswa Melalui Media Picture and Picture Pada Materi Penerapan Sila-sila Pancasila" 2017.

Djamarah, S. B., \& Zain, A. (2006). Strategi belajar mengajar. Jakarta: Rineka Cipta, 46.

Hamalik, U. (1989). Teknik pengukuran dan evaluasi pendidikan. Mandar Maju.

Imas Kurniasih dan Berlin 2015. Ragam Pengembangan Model Pembelajaran Untuk Peningkatan Profesionalitas Guru. Jakarta: Kata Pena.

http://library.uny.ac.id/sirkulasi/index.php?p=show detail\&id=53902

Poerwanti, E. (2008). Asesmen pembelajaran SD. Jakarta: Depdiknas.

Satria Adi Nugroho dan Riyadi dan Yulianti, "Pengaruh Pendekatan Realistik

Mathematics Education (RME) Terhadap Hasil Belajar Matematika Pada Materi

Geometri”, Jurnal, hal. 1 (Wilantara dkk, 2016.)

Sudjana. 2005. Metode statistik. Bandung: Tarsito.

https://library.unismuh.ac.id/opac/detail-opac?id=104600

Sumantri, Mulyani. (2014) Perkembangan Peserta Didik. Banten : Universitas Terbuka.

https://pustaka.ut.ac.id/lib/mkdk4002-perkembangan-peserta-didik/

Surya Hendra. 2009 . Menjadi Manusia Pembelajar. Jakarta: Elex Media Komputindo.

https://library.ui.ac.id/detail?id=20284975

Tiara Dewi, Muhammad Amir Masruhim, R. S. (2016). Model Pembelajaran Picture and Picture untuk Meningkatkan Pemahaman Sejarah. Laboratorium Penelitian Dan Pengembangan FARMAKA TROPIS Fakultas Farmasi Universitas Mualawarman, Samarinda, Kalimantan Timur, April, 5-24.

Trianto (2009).Mendesain Model Pembelajaran Inovatif Progresif.Surabaya:Kencana http://digilib.unimed.ac.id/25407/4/15.DAFTAR\%20PUSTAKA\%20\%20NAMA\%20RA 


\section{HUT\%20SILVIA\%20SIAHAAN\%20NIM\%201133311012.pdf}

Trisnawati, N. N. L., Suarni, N. K., \& Agung, A. A. G. (2014). Penerapan Metode Picture and Picture Dengan Media Cerita Gambar Berseri Untuk Meningkatkan Perkembangan Bahasa Anak. Journal PG-PAUD Universitas Pendidikan Ganesha, 2(1), 1-10.

https://ejournal.undiksha.ac.id/index.php/JJPAUD/article/download/3149/2617 